\title{
The importance of the Dacron cuffs in peritoneal dialysis catheters for acute kidney injury applied in veterinary medicine
}

\author{
DOI: $10.35530 / I T .070 .04 .1685$
}

BOGDAN ALEXANDRU VIȚĂLARU

ALEXANDRA GABRIELA ENE

LAURENTIIU ALEXANDRU CHIOTOROIU

\section{REZUMAT - ABSTRACT}

Importanța manșetelor de Dacron în cateterele pentru dializă peritoneală pentru leziunile renale acute din medicina veterinară

Dializa peritoneală este o tehnică recomandată la pacienții care prezintă uremie nonanurică acută atunci când azotul uremic din sânge (BUN) atinge niveluri de peste $100 \mathrm{mg} / \mathrm{dl}$ sau când creatinina este mai mare de $10 \mathrm{mg} / \mathrm{dl}$. Cateterele pentru dializă acută sunt plasate percutanat, sub anestezie locală, iar cateterele concepute pentru dializă peritoneală cronică au două manșete de Dacron și sunt plasate sub anestezie generală. În acest studiu am selectat 24 de câini, atât masculi, cât și femele cu vârsta cuprinsă între doi și 14 ani, cu ARA, care au făcut dializă peritoneală între 14 zile și 29 de zile. S-au creat două grupuri de pacienți: grupul (A) cu pacienți tratați utilizând un cateter normal peritoneal pentru tratament acut, fără manșete de Dacron și cel de-al doilea grup (B) cu pacienți tratați folosind un cateter peritoneal pentru tratamentul cronic, cu două manșete de Dacron. $75 \%$ dintre pacienții din primul grup au prezentat acumulare de soluție de dializat la nivel subcutanat, ceea ce arată că manșetele Dacron sunt foarte eficiente în prevenirea scurgerii lichidului peritoneal sub piele. Omentectomia este recomandată datorită riscului ridicat de blocare a cateterului de către omentum, dar se recomandă efectuarea acesteia în condiții de maximă siguranță, în ceea ce privește condițiile de asepsie și antisepsie. Peritonita este o complicație majoră a dializei peritoneale, 33.33\% din primul grup, prezentând această complicație și doar $8.33 \%$ din al doilea grup.

Cuvinte-cheie: peritoneal, dializă, cateter, Dacron, manșete, veterinar

The importance of the Dacron cuffs in peritoneal dialysis catheters for acute kidney injury applied in veterinary medicine

Peritoneal dialysis is a technique indicated in patients showing acute nonanuric uremia, when blood urea nitrogen (BUN) reaches levels over $100 \mathrm{mg} / \mathrm{dl}$ or when creatinine is higher than $10 \mathrm{mg} / \mathrm{dl}$. Catheters for acute dialysis are placed percutaneously, under local anaesthesia and catheters designed for chronic peritoneal dialysis have two Dacron cuffs and are placed under general anaesthesia. In this study we have selected 24 dogs, both males and females with age between two and 14 years old, with AKI, undergoing peritoneal dialysis between 14 days and 29 days. We have created two groups of patients: group (A) treated using a normal peritoneal catheter for acute treatment, without Dacron cuffs and the second group $(B)$ treated using a peritoneal catheter for chronic treatment, with two Dacron cuffs. $75 \%$ of patients from the first group were found with accumulation of the dialysate solution at the subcutaneous level, which shows that Dacron cuffs are very efficient in preventing the peritoneal fluid to leak under the skin. Surgical omentectomy is strongly recommended due to the high risk of catheter blockage by the omentum, but it is recommended to be performed under maximum safety with regard to asepsis and antisepsis conditions. Peritonitis is a very important complication of the peritoneal dialysis technique, 33.33\% from the first group, presenting this complication, and only 8.33\% form the second group having it.

Keywords: peritoneal, dialysis, catheter, Dacron, cuffs, veterinary

\section{INTRODUCTION}

The first and foremost indication for peritoneal dialysis in dogs and cats is anuria generated by an acute kidney injury (AKI) that is unresponsive to fluid therapy. Dialysis is also indicated in patients showing acute nonanuric uremia, when blood urea nitrogen (BUN) reaches levels over $100 \mathrm{mg} / \mathrm{dl}$ or when creatinine is higher than $10 \mathrm{mg} / \mathrm{dl}$ [1].

Peritoneal dialysis is contraindicated in patients with peritoneal adhesions, fibrosis or abdominal malignant tumors [1].
The ideal catheter for dialysis allows for an adequate administration and evacuation of the dialysate, it determines minimum subcutaneous losses, it minimizes infection both in the peritoneal cavity and in the subcutaneous tissue [2].

Catheters for acute dialysis are placed percutaneously, under local anaesthesia, with the help of a stiletto and they require immediate heparinization. These catheters are usually straight with orifices at the distal end. Acute catheters generally do not have Dacron cuffs in order to protect the patient against bacterial infection and catheter migration, that may 
lead to a high peritonitis rate in case of extensive use [3].

Catheters for chronic peritoneal dialysis have specific models, both intraperitoneal and extraperitoneal, in order to reduce secondary effects and to minimize blockage. These catheters are made of silicon, rubber or polyurethane [3].

Catheters designed for chronic peritoneal dialysis have Dacron cuffs meant to protect the patient against bacterial infection and catheter migration that may lead to a high peritonitis rate in case of extensive use [2].

The intraperitoneal segment of catheters has numerous lateral orifices at the distal end that allow the free flow of dialysate. The distal end of the peritoneal dialysis catheter may be straight or coiled. The coiled end may help with avoiding blockage. The segment of the catheter that comes out of the abdomen usually presents one or two Dacron cuffs. The Dacron cuffs generate a local inflammatory response that triggers the emergence of granulation or fibrous tissue. This tissue fixes in place the catheter and it prevents the migration of bacteria from skin to the peritoneal cavity [4].

There are no studies performed in veterinary medicine meant to assess the practicality of a certain type of catheter for peritoneal dialysis [5].

In cases of extreme emergency, when the peritoneal dialysis should not be used more than 72 hours, the placement of a short term catheter is justified [6-7].

When placing a peritoneal dialysis catheter, which is meant to be used for more than three days, it is recommended to use a permanent catheter. The longterm peritoneal dialysis catheter should be surgically placed. The surgical placement of the catheter allows the visualization of the abdominal cavity and it is useful in omentectomy. Surgical omentectomy is also recommended due to the high risk of catheter blockage by the omentum [7-8].

Afterwards, it is possible to take the final step, placing the long term peritoneal dialysis catheter [2].

Once surgically placed, in human medicine, peritoneal dialysis catheters should be used after at least 10 to 14 days. This period of time allows for wound healing, scar formation around the Dacron cuffs and minimization of dialysate leakage around the penetration site of the catheter. For obvious reasons, in veterinary medicine, peritoneal dialysis requires the immediate use of the peritoneal catheters, since most of the cases are major emergencies and they cannot be postponed for such a duration of time [2].

Polyethylene terephthalate forms the basis for synthetic fibres like Dacron, Terylene and polyester. Polyester is a category of polymers that contain the ester functional group in their main chain. As a specific material, it most commonly refers to a type called polyethylene terephthalate [7-8].

In this study, we have tested peritoneal catheters with Dacron cuffs and peritoneal catheters without Dacron cuffs.

\section{MATERIALS AND METHODS}

In this study we have selected 24 dogs, both males and females with $\mathrm{AKI}$ undergoing peritoneal dialysis. The study started in January 2014 and finished in December 2018. All patients were tested for other associated pathologies and none of the selected patients presented other morbidities of infections of the peritoneal cavity or at the skin, around the catheter placement area.

The patients' age has two to 14 years old and the longest period that they were submitted to peritoneal dialysis has 29 days. The shortest period of treatment was 14 days.

The diseases that were treated were: acute intoxication with ethylene glycol, babesiosis, raisin intoxication, acute obstruction of the urethra, urinary bladder rupture.

We have created two groups of patients: first group (A) of 12 patients were treated using a normal peritoneal catheter for acute treatment, without Dacron cuffs and the second group of 12 patients $(B)$ were treated using a peritoneal catheter for chronic treatment, with two Dacron cuffs.

In the first group, the peritoneal catheter was placed percutaneously, under local anaesthesia, with the help of a stiletto and they required immediate heparinization. The catheters were fixed in place by suturing the skin with a non-absorbable monofilament thread ranging from $4 / 0$ to $2 / 0$.

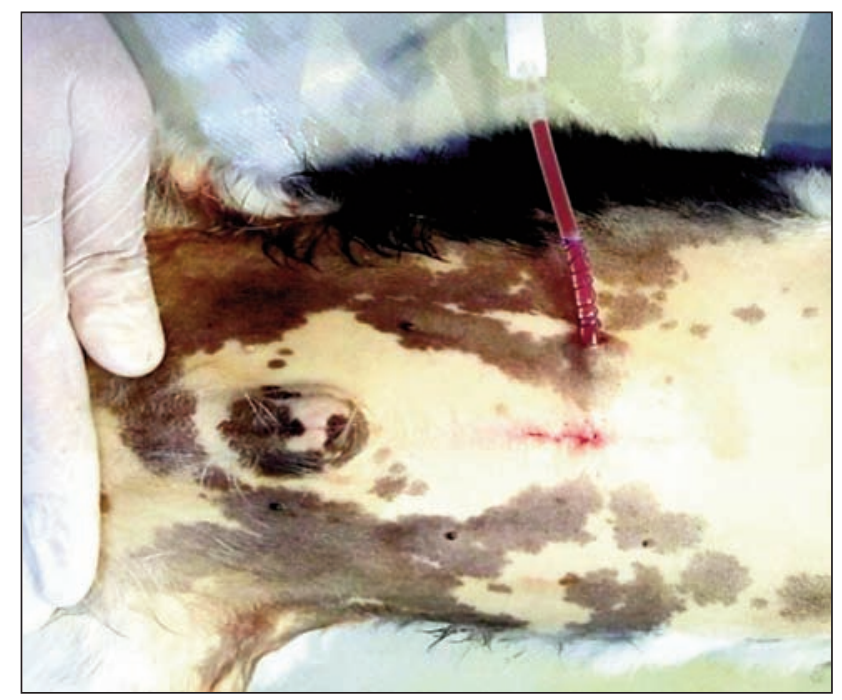

Fig. 1. Roman sandal suture for the temporary peritoneal catheter in dogs with $\mathrm{AKI}$ (orig.)

The patients from the second group needed general anaesthesia and the catheters were placed using a surgical technique. The surgical placement of the catheter allowed the visualization of the abdominal cavity and it is useful in omentectomy. Surgical omentectomy was also recommended due to the high risk of catheter blockage by the omentum [9]. Peritoneal dialysis catheters were trimmed (cut), resizing them at the desired level for entering the peritoneal cavity, in order to reach the bottom of the Douglas pouch. 
The catheters were pre-measured and, after being cut, they were inserted into the cavity. The abdominal muscles were sutured using an absorbable monofilament thread and the last suture, or a separate suture point, was anchored in the distal Dacron cuff of the peritoneal catheter. Subsequently, the anterior end of the catheter was passed through a subcutaneous lateral tunnel and it was exteriorized through the skin at 3-5 cm from the main incision line, so that the second Dacron cuff was located at subcutaneous level. We used Roman sandal technique in all patients as the safest and easiest method to place and maintain sutures in the case of a peritoneal dialysis catheter.

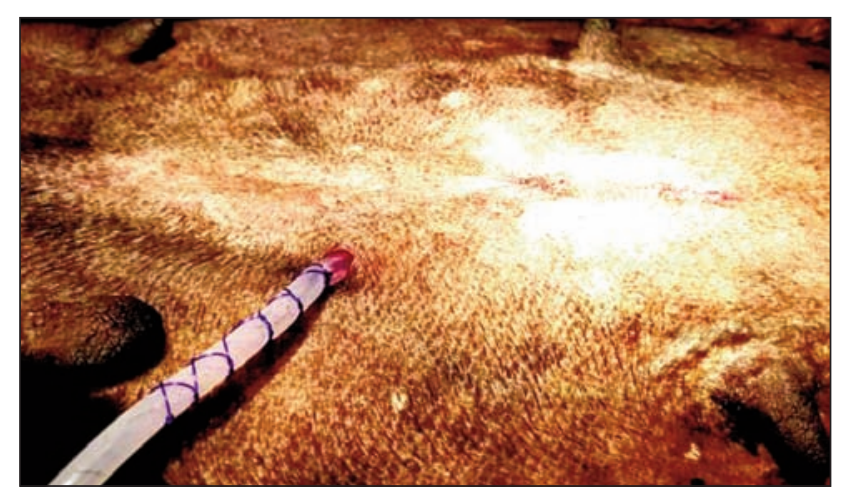

Fig. 2. Roman sandal suture for the permanent peritoneal catheter in dogs with AKI (orig.)

\section{RESULTS AND DISCUSSIONS}

After analysing all the data form the patient undergoing peritoneal dialysis, we have reached important data. All cases were successfully, none of the patients died and all of the patients recovered fully after the treatment, without presenting any kidney impairment according to the IRIS scale.

The patients from the first group, having placed temporary dialysis catheters were found with accumulation of the dialysate solution at the subcutaneous level. This happened in 9 form 12 cases (75\%). None of the patients from the second group, having placed permanent dialysis catheters were found with accumulation of the dialysate solution at the subcutaneous level.

Peritoneal catheter obstruction was found in 11 form 12 patients $(91.66 \%)$ from the first group having

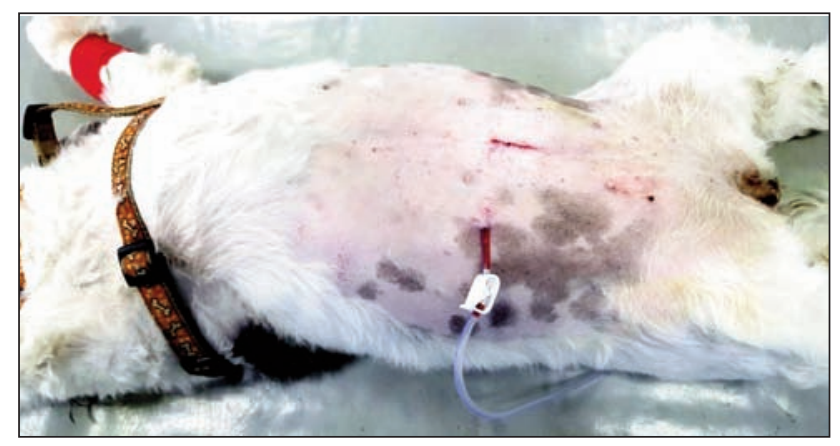

Fig. 3. Accumulation of the dialysate solution at the subcutaneous level in dogs with AKI (orig.) placed temporary dialysis catheters, because all these patients had the omentum in place and dialysis solution retention (the recovery of less than $90 \%$ of the dialysate solution) represented a very common finding. None of the patients from the second group, having placed permanent dialysis catheters had problems in peritoneal dialysis fluid recovery.

Peritonitis was diagnosed in four out of 12 patients (33.33\%) from the first group, having placed temporary dialysis catheters. Peritonitis was considered when two of the three following criteria are identified: turbid dialysate fluid when extracted, extracted dialysate fluid with more than 100 inflammatory cells/ $\mu \mathrm{L}$, or a positive bacterial culture test in the extracted dialysate solution, and clinical symptomatology characteristic of peritonitis. The dialysate solution was contaminated with Escherichia coli, Klebsiella or Enterococcus. Just one of the 12 patients (8.33\%) from the second group, having placed permanent dialysis catheters was found with peritonitis and the fluid culture showed Escherichia coli infection.

The only disadvantage of the technique for placing the permanent dialysis catheters is a longer working duration for the procedure, higher costs, and a longer incision for the catheter placement.

Table 1

\begin{tabular}{|l|c|c|c|c|}
\hline \multicolumn{3}{|c|}{ RESULTS OBTAINED AFTER ANALYSING ALL THE } \\
DATA FROM THE PATIENTS IN THE TWO GROUPS \\
\hline \multicolumn{1}{|c|}{ Results } & \multicolumn{2}{|c|}{ GROUP A } & \multicolumn{2}{c|}{ GROUP B } \\
\cline { 2 - 5 } & Number & Percent \% & Number & Percent \% \\
\hline $\begin{array}{l}\text { Sc fluid } \\
\text { accumulation }\end{array}$ & 9 & 75 & 0 & 0 \\
\hline $\begin{array}{l}\text { Peritoneal } \\
\text { catheter } \\
\text { obstruction }\end{array}$ & 11 & 91.66 & 0 & 0 \\
\hline Peritonitis & 4 & 33.33 & 1 & 8.33 \\
\hline
\end{tabular}

\section{CONCLUSIONS}

Using a permanent dialysis catheters needs a longer working duration for the procedure, with higher costs, and a longer incision for the catheter placement, but with less risks.

In our study, $75 \%$ of patients from the first group, having placed temporary dialysis catheters were found with accumulation of the dialysate solution at the subcutaneous level, which shows that Dacron cuffs are very efficient in preventing the peritoneal fluid to leak under the skin.

Surgical omentectomy is strongly recommended due to the high risk of catheter blockage by the omentum, but it is recommended to be performed under maximum safety with regard to asepsis and antisepsis conditions.

Peritonitis is a very important complication of the peritoneal dialysis technique, $33.33 \%$ from the first group, having placed temporary dialysis catheters presenting this complication, and only $8.33 \%$ form the second group having it. 


\section{BIBLIOGRAPHY}

[1] Acierno, M.J., Labato, Mary, Kidney Diseases and Renal Replacement Therapies, An Issue of Veterinary Clinics: Small Animal Practice, Elsevier-Saunders, Ottawa, 2011

[2] Vițălaru, A.B, Ștefănescu, Alina, Peritoneal Dialysis in small animals, Ed. Printech, București, 2018

[3] McQuiston, Jennifer H., Ehrlichiosis and Related Infections, The Merck Veterinary Manual, 2014

[4] Stokes, J.E., Bartges, J.W., Causes of acute renal failure, Compend Contin Educ Pract Vet, 2006

[5] Stojimirovici, B., Trbojevic-Stankovic, J., Animal models in peritoneal dyalisis, In: Scand. J. La. Anim. Sci., 2007, 34, 4

[6] Thornhill J.A., Peritoneal dialysis in the dog and cat: an update, In: Compend Cortin Educ Prac Vet, 1981, 3, pp. 20-34

[7] Thornhill, J.A., Peritonitis associated with peritoneal dialysis: diagnosis and treatment, In: J Am Vet Assoc., 1983, 182, p. 721

[8] Kushwaha, R., Singh, N., Peritoneal dialysis in animals - A review, In: The Internet Journal of Veterinary Medicine, 2008, 7, 12008

[9] Vasileacu, D., Ionita, S., Grama, V., Pelinaru, A., Chiotoroiu, A., Alloplastic parieto-synthesis complications in abdominal wall reconstructivesurgery - our clinical experience, In: Industria Textila, 2018, 69, 2, pp. 133-140

\section{Authors:}

\section{BOGDAN ALEXANDRU VIȚĂLARU ${ }^{1}$, ALEXANDRA GABRIELA ENE²,}

\section{LAURENTIU ALEXANDRU CHIOTOROIU ${ }^{3}$}

${ }^{1}$ University of Agricultural Sciences and Veterinary Medicine Bucharest, Faculty of Veterinary Medicine Bucharest, Department of Clinical Sciences, Splaiul Independenței, 105, Bucharest, e-mail: alexandrumv@yahoo.com

${ }^{2}$ The National Research and Development Institute for Textiles sand Leather, IT Research Department in Industrial Engineering, Department, 030508, Bucharest, Romania e-mail: alexandra.ene@certex.ro

${ }^{3}$ General Surgery - Emergency Hospital Bucharest Romanaia e-mail: chiotoroiu@yahoo.com

Corresponding author: BOGDAN ALEXANDRU VIȚĂLARU e-mail: alexandrumv@yahoo.com 